UDK 519.246.8

\author{
A.A. BROVARETS \\ Kyiv Cooperative Institute of Business and Law, Kyiv \\ Y.V. CHOVNYUK \\ National University of Environmental and Life Sciences of Ukraine, Kyiv \\ V.T. KRAVCHYUK \\ Kyiv National University of Construction and Architecture, Kyiv \\ E.A. IVANOV \\ National Aviation University, Kyiv
}

\title{
THE QUALITATIVE FRACTAL ANALYSIS OF LONG TERM TIME SERIES FOR AGRICULTURAL SOILS' ELECTRICAL CONDUCTIVITY PARAMETERS: METHODS OF NONLINEAR DYNAMICS, THEORY OF CHAOS, PHASE TRAJECTORIES
}

The procedure of the qualitative fractal analysis of long term time series for agricultural soils' electrical conductivity parameters, for which the hypothesis of trend existence isn't confirmed, with application of the methods of nonlinear dynamics, theory of chaos and phase trajectories, is presented. The real time series characterizing mentioned above electrical conductivity parameters of Ukrainian soils are considered. The basis for similar researches is Takens's theorem. The randomness of the studied dynamical system given by time realizations is established by means of Lyapunov's indicator. The state stability is estimated by Hausdorff 's fractal dimension and the fractality index. Visual evaluation of the time series was carried out by means of the phase trajectory restoration procedure. As a result of the analysis of phase points in the phase space the split attractor is indicated, which gives the chaise to speak about its bifurcation.

Application of the nonlinear dynamical system theory methods to the time series analysis is based on the hypothesis that the available series describes the behavior of the studied system, and it's the only available information about this system. According to the well-known Takens's theorem [1] a single time series suffices for an adequate description of a dynamical system as a whole.

The analysis of time series by the methods of nonlinear dynamical system theory is becoming widely applied. In terminology of this theory the process described by time series contains the deterministic chaos, or, in other words, is chaotic. From the linear analysis method point of view they are stochastic processes.

The nonlinear analysis demonstrates that neither can these processes be considered as deterministic ones, nor are they absolutely random. In other words, only short-term forecasting of the system condition is possible with certain accuracy.

Keywords: qualitative fractal analysis, long term, time series, agricultural soils, electrical conductivity, parameters, methods of nonlinear dynamics, theory of chaos, phase trajectories, Lyapunov's indicator, fractal dimension, fractality index, phase space, attractor, bifurcation of an attractor.

О.О. БРОВАРЕЦЬ

Київський кооперативний інститут бізнесу і права, Київ

Ю.В. ЧОВНЮК

Національний університет біоресурсів і природокористування України, Київ

В.Т. КРАВЧУК

Київський національний університет будівництва і архітектури, Київ

C.O. IBAHOB

Національний авіаційний університет, Київ

\section{ЯКІСНИЙ ФРАКТАЛЬНИЙ АНАЛІЗ ДОВГОТРИВАЛИХ ЧАСОВИХ РЯДІВ ПАРАМЕТРІВ ЕЛЕКТРОПРОВІДНОСТІ ГРУНТІВ \\ СІЛЬСЬКОГОСПОДАРСЬКОГО ПРИЗНАЧЕННЯ: МЕТОДИ НЕЛІНІЙНОЇ ДИНАМІКИ, ТЕОРІЇ ХАОСУ, ФАЗОВИХ ТРАЕКТОРІЙ}

\footnotetext{
Запропоновано процедуру якісного фрактального аналізу довготривалих часових рядів параметрів електропровідності грунтів сільськогосподарського призначення, для яких не підтверджується гіпотеза про наявність тренда, із застосуванням методу нелінійної динаміки, теорії хаосу та фазових
} 
траєкторій. Розглянуті реальні часові ряди, щзо характеризують згадані параметри електропровідності украӥнських трунтів (сільськогосподарського призначення). Обтрунтуванням для подібних досліджень є теорія Такенса. Хаотичність досліджуваної динаміки системи, що задана часовими реалізаціями, встановлена за допомогою показника Ляпунова. Оиінка стійкості стану оцінювалась фрактальною розмірністю Хаусдорффа й індексом фрактальності. Візуальна оцінка часового ряду проводилась за допомогою процедури відновлення фазових траєкторій. У результаті аналізу фазових точок фазового простору виявлені ознаки розщепленого аттрактору, щзо дає можливість говорити про його біфуркацію.

Застосування методів теорії нелінійних динамічних систем до аналізу часових рядів базується на гіпотезі про можливість опису поведінки досліджуваних систем подібним чином, й до того ж ие єдина доступна інформаџія про систему. Згідно з добре відомою теоремою Такенса [1], одного часового ряду для адекватного опису динамічної системи цілком достатньо.

Аналіз часових рядів методами теорії нелінійних динамічних систем зараз набуває иирокого застосування. Згідно з термінологією цієї теорії, процес, який описується часовими рядами, може утримувати у собі детермінований хаос, або, іншими словами, стає хаотичним. 3 точки зору методу лінійного аналізу, такі прочеси є хаотичними.

Нелінійний аналіз демонструє те, щзо такі процеси можна розглядати або як детерміновані, або як абсолютно стохастичні. Іншими словами, тільки короткотривале прогнозування поведінки системи є можливим з певною точністю.

Ключові слова: якісний фрактальний аналіз, довготривалість, часові ряди, трунти сільськогосподарського призначення, параметри, електропровідність, методи нелінійної динаміки, теорія хаосу, фазові траєкторії, показник Ляпунова, фрактальна розмірність, індекс фрактальності, фазовий простір, аттрактор, біфуркація аттрактору.

А.А. БРОВАРЕЦ

Киевский кооперативный институт бизнеса и права, Киев

Ю.В. ЧОВНЮК

Национальный университет биоресурсов и природопользования Украины, Киев

В.Т. КРАВЧУК

Киевский национальный университет строительства и архитектуры, Киев

Е.А. ИВАНОВ

Национальный авиационный университет, Киев

\section{КАЧЕСТВЕННЫЙ ФРАКТАЛЬНЫЙ АНАЛИЗ ДЛИТЕЛЬНЫХ ВРЕМЕННЫХ РЯДОВ ПАРАМЕТРОВ ЭЛЕКТРОПРОВОДНОСТИ ГРУНТОВ СЕЛЬСКОХОЗЯЙСТВЕННОГО ПРЕДНАЗНАЧЕНИЯ: МЕТОДЫ НЕЛИНЕЙНОЙ ДИНАМИКИ, ТЕОРИИ ХАОСА, ФАЗОВЫХ ТРАЕКТОРИЙ}

\footnotetext{
Предложена прочедура качественного фрактального анализа длительных временных рядов параметров электропроводности грунтов сельскохозяйственного предназначения, для которых не подтверждается гипотеза о наличии тренда, с использованием методов нелинейной динамики, теории хаоса и фазовых траекторий. Рассмотрены реальные временные ряды, которые характеризуют упомянутые выме параметры электропроводности украинских грунтов (сельскохозяйственного предназначения). Обоснованием для подобных исследований является теорема Такенса. Хаотичность исследуемой динамической системы, которая задана временными реализачиями, установлена с помощью показателя Ляпунова. Оченка устойчивости состояния оценивалась фрактальной размерностью Хаусдорффа и индексом фрактальности. Визуальная оценка временного ряда производилась с помощью процедуры восстановления фазовых траекторий. В результате анализа фазовых точек фазового пространства вылвлень признаки расщепленного аттрактора, что дает возможность говорить о его бифуркации.

Применение методов теории нелинейных динамических систем к анализу временных рядов базируется на гипотезе о возможности описания поведения исследуемых систем подобным образом, кроме того, это единственная доступная информация о системе. В соответствии с хорошо известной теоремой Такенса [1], одного временного ряда вполне достаточно для адекватного описания динамической системы.

Анализ временных рядов методами теории нелинейных динамических систем сейчас приобретает широкое применение. В соответствии с терминологией этой теории, процесс, который описывается
} 
временными рядами, может содержать в себе детерминированный хаос или, иными словами, стаёт хаотическим. С точки зрения метода линейного анализа, такие прочессы являются хаотическими.

Нелинейный анализ демонстрирует то, что такие процессы можно рассматривать либо как детерминированные, либо как абсолютно стохастические. Иными словами, только краткосрочное прогнозирование поведения системь является возможным с определенной точностью.

Ключевые слова: качественный фрактальный анализ, долгосрочность, временнье ряды, грунтьл сельскохозяйственного предназначения, параметры, электропроводность, методы нелинейной динамики, теория хаоса, фазовые траектории, показатель Ляпунова, фрактальная размерность, индекс фрактальности, фазовое пространство, аттрактор, бифуркаџия аттрактора.

\section{Introduction}

The system model is constructed by observed variables. In medicine, ecology, sociology the dynamics of a research object is tracked by time realizations - time series. As a rule, in the time series analysis the methods giving the quantitative forecast (point or interval) are used. For the time series, for which the hypothesis of trend existence isn't confirmed, such methods aren't productive.

Application of the nonlinear dynamical system theory methods to the time series analysis is based on the hypothesis that the available series describes the behavior of the studied system, and it's the only available information about this system. According to the well-known Takens's theorem [1] a single time series suffices for an adequate description of a dynamical system as a whole.

The analysis of time series by the methods of nonlinear dynamical system theory is becoming widely applied. In terminology of this theory the process described by time series contains the deterministic chaos, or, in other words, is chaotic. From the linear analysis method point of view they are stochastic processes.

The nonlinear analysis demonstrates that neither can these processes be considered as deterministic ones, nor are they absolutely random. In other words, only short-term forecasting of the system condition is possible with certain accuracy.

Today, the chaos theory remains one of the most widespread ways of forecasting and researching the dynamical system state stability. The purpose of the system stability analysis is identification of all its stationary states. If at least one of the stationary states is for any reasons threatening or undesirable, then its existence gives the chance to develop the preventive measures reducing the probability of the system transition to this state.

One of the most common forms of stability loss is the system state randomization [1]. The mechanisms of system transition to such state are studied insufficiently. However, the fact that such state is possible requires developing new system research methods. The research tools of the chaos theory are attractors and fractals. The two prevailing dynamical system randomness criteria are Lyapunov's indicator and the fractal dimension.

\section{Related publications survey}

In [3] it's proved that the low information content of statistical indicators results from the fractal properties intrinsic to the behavior of time series, which empirical distribution function doesn't conform with the normal distribution. Therefore for detection of the general tendency of time series behavior it is offered to use chaos theory methods giving the chance to carry out the qualitative analysis of the studied time series at the stage of preliminary analysis. On relation to the dynamics of social and natural systems and processes the chaos theory not only explains the bifurcation phenomena (big falling or big emissions) but also claims that they can't be predicted because the nature isn't a of the repeating regularities, but is characterized by local randomness and a global order. For this reason many analysts have reasonably assumed that the fractal nature of time series will help then to recognize new regularities in the chaotic movement [4-7]. 
The main formal characteristics of chaotic processes in the nonlinear dynamical system theory are the phase space and the attractor. One of the system chaotic behavior features is instability of the trajectories belonging to the attractor. Quantitatively this instability is measured by Lyapunov's characteristic indicators. Since the existence of the highest positive Lyapunov's indicator is the criterion of chaotic dynamics, the possibility of its evaluation on the basis of processing the given time series is naturally interesting.

Commonly, nonlinear dynamical systems have fractal attractors, this is means that unstable phase trajectories of the systems tend to become fractals in time [3]. On important moment of the fractal approach is the influence of the random process prehistory on the behavior of the system today. Therefore, this method of the analysis of time series is of particular interest to the researches.

As a rule, in nature real pure fractals don't exist, and it's possible to speak only about the fractal phenomena. They should be considered merely as models which are fractals approximately in statistical sense. A lot of experimental data have fractal statistics, which can be analyzed and modeled by means of fractal analysis methods [4, 5].

One of the most popular directions of the fractal analysis is over time studying of the dynamics of such characteristic as fractal dimension. This indicator characterizes the repeatability of statistical values of natural time series with changing scale. The fractal dimension introduced by Hausdorff and D-dimension is the main characteristic of fractal structures $[6,7]$.

There are several methods of determining the fractal dimension for time series considered as a set of observable parameters of the studied dynamical system overtime. We'll focus on two of them. First of all, it's the classical way of cellular coverage of the time series graphic representation in which the fractal dimension is defined the same way as for geometrical fractals. The second approach for studying fractal time series was offered by Benoit Mandelbrot. It's based on the researches of the English scientist Hurst and called the $R / S$ - method.

For the majority of real time series it's impossible to determine the fractal dimension analytically. Therefore, the $V$ alne $D$ are quantified, for example, through the Hurst index. In the time series analysis the influence of the present on the future can be expressed by the ratio $C=2^{2 H-1}-1[8]$.

If a set of flat geometrical figures (cells) with the general geometrical parameters $\delta$ is considered as the time series approximation, then by Hausdorff's definition the $D-$ dimension is determined by the law $S(\delta) \approx \delta^{2-D}$ as $\delta \rightarrow 0$, where $S^{\prime}(\delta)$ is the total area of the cells with fragmentation scale $\delta$.

One of the time series stability indicators is the fractality index $\mu$ [9-11]. In particular, the advantage of this index before other fractal indicators is that for computing this index with an acceptable accuracy data two orders less than for computing the Hurst indicator $H$ index. It gives the chance to carry out the time series local fractal analysis based on the properties of the function $\mu(t)$.

Chaos in dynamical systems implies dynamics`evolution sensitivity to initial conditions changes. It means that two trajectories, close to each other in the phase space at some initial time point, diverge exponentially after rather small then the average time $t$. If $d_{0}$ is the distance between two starting points at the initial time point, then after time $t$ distance between the trajectories leaving these points becomes $d(t)=d_{0} \cdot \exp (2 \cdot \lambda \cdot t)$ or $d_{n}=d_{0} \cdot \exp (2 \cdot \Lambda \cdot t)$ in case the system is described by different equations. 
The numbers $\lambda$ and $\Lambda$ are called Lyapunov's indicators. Variable $d(t)\left(d_{n}\right)$ can't increase infinitely because of the system limitation. It gives the opportunity to determine the measure of trajectory divergence by averaging the exponential growth on trajectory points. Then Lyapunov's indicator can be written down as

$$
\lambda=\frac{1}{\left(t-t_{0}\right)} \cdot \sum_{k=1}^{n} \ln \left(\frac{d\left(t_{k}\right)}{d\left(t_{k-1}\right)}\right)
$$

It is possible to calculate $\lambda(\Lambda)$ in an explicit form only in some cases, such as, for instance, the case of one-dimensional displays: $X_{n+1}=f\left(x_{n}\right)$. When $f(x)$ is smooth and differentiable the distance between the neighboring trajectories is measured by the value $\left|f^{\prime}(x)\right|$. In the case of chaos criterion it's enough to calculate the highest Lyapunov's indicator only.

The review on Lyapunov's indicators and their usage as the movement randomness criterion is given in [2]. Here the references to the existing software products for calculation of these indicators can also be found.

One of the widespread ways of time series visual evaluation relies on the phase trajectory restoration procedure. Possibilities of such phase portrait visual analysis are very limited. However, for identification of complex non periodic time realization the phase portrait analysis gives sometimes more information than the data spectral analysis. The advantage of this approach is also that it's applied independently of the fact whether the research object model is constructed or not. Since it's not always possible to receive a suitable model in practice, the real way of the system stability analysis is the non model way of the phase trajectory behavior analysis.

\section{Problem setting}

The purpose of this research is the analysis of stability of the electrical conductivity parameter of agricultural soils by its time realization using the phase trajectory analysis and qualitative fractal analysis methods.

We determine the fractal dimension for time series by the classical method of cellular coverage of time series graphic image.

Let the observations of scalar equidistant time series of electrical conductivity parameter for agricultural soil be considered as $\left(X\left(t_{i}\right)\right)_{i=1}^{N}$ for the one interval $[0, T]$. We divide the interval into $m$ parts by the points $\mathrm{O}, \tau_{0}, \tau_{1}, \tau_{2} \ldots . \tau_{m}, T$, where $\tau_{i}-\tau_{i-1}=\delta, \delta=\frac{T}{m},(i=\overline{1, m})$. We denote such uniform partition of the time series $\left(X\left(t_{i}\right)\right)_{i=1}^{N}$ realization interval by $\omega_{m}$.

We cover the time series image with rectangles with the base $\delta$ (scale $\delta$ ). It's clear, that the height of the rectangle on the interval $\left[\tau_{i,} \tau_{i-1}\right\rfloor$ is equal to the variation range, $A_{i}(\delta)$ of the time series values $x\left(t_{i}\right)$ on this interval. We calculate the value $V(\delta)=\sum_{i=1}^{m} A_{i}(\delta)$. Then the area of such minimal coverage is $S(\delta)=V(\delta) \cdot \delta$.

By comparing this equality with Hausdorff's $D$-dimension definition, in [q] it's proved that $S(\delta) \approx \delta^{2-D}$ and $V(\delta)=\delta^{-\mu}$, where $\mu=D_{\mu}-1$. The value $D_{\mu}$ is called the minimal coverage dimension, and $\mu$ is the fractality index. 
When calculating the index $\mu$ in the present research the sequence of $n$ enclosed partition $\omega_{m}$, where $m=2^{n}, n=0,1,2,3,4,5,6$ was used. Each partition consisted of $2^{n}$ intervals containing $2^{6-n}$ observations $x\left(t_{i}\right)$. At the same time, the periods with abnormally large values $x\left(t_{i}\right)$ were excluded from the available realization of the time series $\left(X\left(t_{i}\right)\right)_{i=1}^{N}$. The analyzed time series $\left(X\left(t_{i}\right)\right)_{i=1}^{N}$ and constructed for it minimal coverage corresponding to $n=3$ is represented in fig. 1 .

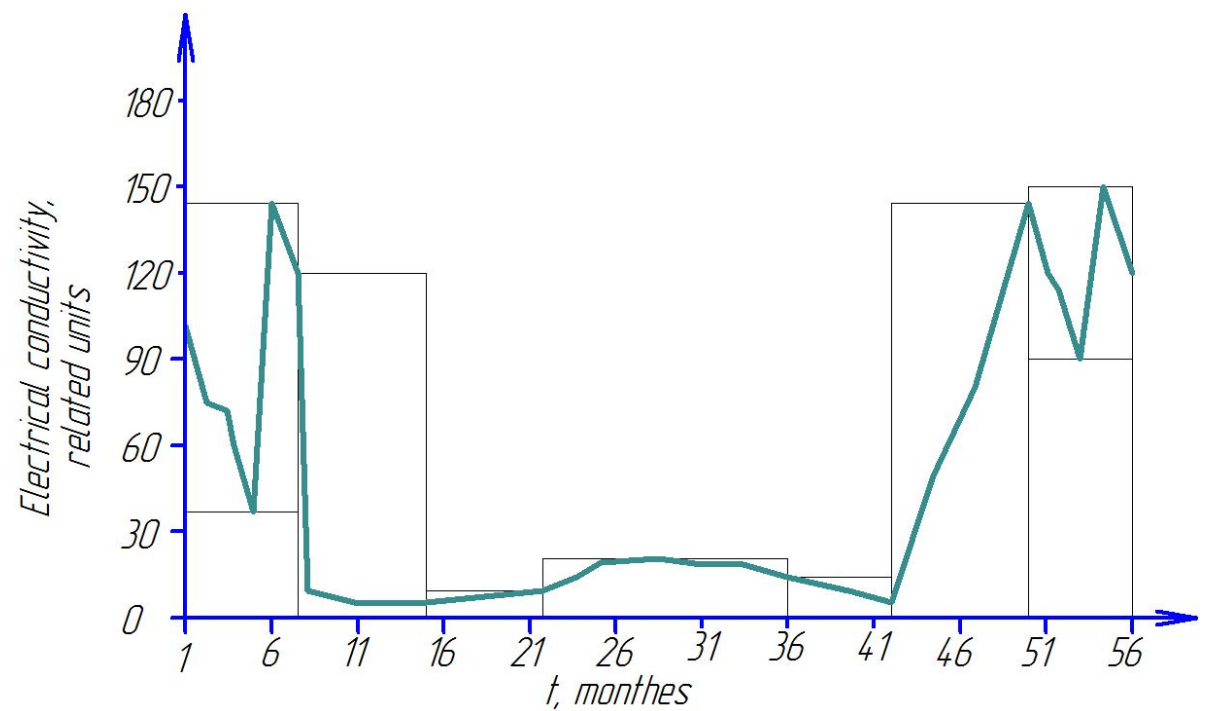

Fig. 1. Minimal cellular coverage for time series characterizing agricultural soil's electrical conductivity

For each partition $\omega_{m}$ the value $V(\delta)$ was calculated. The received results of calculations are given below in Table 1 .

Table 1

Value of variable $\mathbf{V}$ depending on partition scale $\delta$

\begin{tabular}{|c|c|c|c|c|c|c|c|}
\hline $\mathrm{n}$ & 0 & 1 & 2 & 3 & 4 & 5 & 6 \\
\hline $\mathrm{V}$ & 2352,6 & 798,8 & 449,5 & 439,4 & 434,6 & 309,9 & 170 \\
\hline$\Delta$ & 1 & 2 & 3 & 4 & 8 & 16 & 32 \\
\hline
\end{tabular}

At fig. 2 the plot of dependence $V(\delta)$ in double logarithmic scale is represented. For determination of the fractality index $\mu$ from these data by the Ordinary Least Squares method the regression line equation $y=k \cdot x+b$ was set up. Then, according to [10], $\mu=-k$.

In our case the regression equation has the form: $y=-0,66 \cdot x+7,41$. Therefore, at the level of reliability $\alpha=0,90$ the fractality index of the studied series is $\mu=0,66 \cdot x \pm 0,073$. 


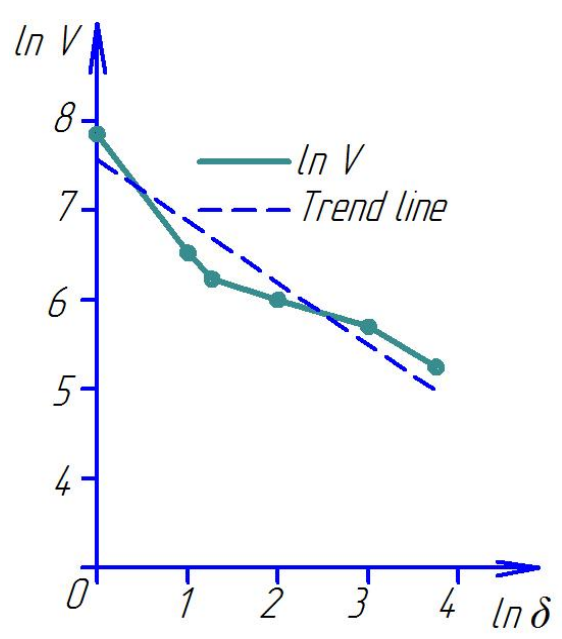

Fig. 2. Dependence of the variable $V(\delta)$ in double logarithmic scale

In the present research the highest Lyapunov's indicator $\lambda\left(x_{1}\right)$ was estimated by the method of comparing phase trajectory evolution points. According to this method, the value $\lambda\left(x_{1}\right)$ for the trajectory $x_{i}=x(t), i=(\overline{1, N})$ of the discrete time series $x_{i+1}=f\left(x_{i}\right)$ was estimated by the formula:

$$
\lambda\left(x_{1}\right)=\lim _{N \rightarrow \infty}\left\{\frac{1}{N} \cdot \sum_{i=1}^{N} \ln \left|f^{\prime}\left(x_{i}\right)\right|\right\},
$$

corresponding to the definition of $\lambda\left(x_{1}\right)$ under the condition that the limit on the right-hand side exist Calculation results of the highest Lyapunov`s indicator $\lambda\left(x_{1}\right)$ for the time series given in fig. 1 are represented in Table 1.

The carried-out calculations have demonstrated that for the given time series $\lambda\left(x_{1}\right) \approx 1,18$, i.e. $\lambda\left(x_{1}\right) \succ 0$ therefore, the trajectory is chaotic.

Table 2

Evaluation of the highest Lyapunov`s indicator $\lambda\left(x_{1}\right)$
\begin{tabular}{|c|c|c|}
\hline $\mathrm{N}$ & $\sum_{i=1}^{N} \ln \mid f^{\prime}\left(x_{i}\right)$ & $\lambda\left(x_{1}\right)$ \\
\hline 10 & 4,013525 & 0,401353 \\
\hline 20 & 3,092552 & 0,154628 \\
\hline 30 & 21,13338 & 0,704446 \\
\hline 40 & 39,99184 & 1,080860 \\
\hline 47 & 55,486649 & 1,180567 \\
\hline
\end{tabular}

Often the situation occur when one lacks the observed values for the dynamical description of an object, that is for setting its state $\vec{x}(t)$ There exit several methods for increasing the number of variables. The time delay method is the simplest and the most popular one. In case of scalar time series the consecutive values of the series $\left(X\left(t_{i}\right)\right)_{i=1}^{N}$ separated by some interval $\tau$ (delay period) are used as the components of the state vector $\vec{x}(t)$. Thus, in the phase plane the state $S_{i}$ of the research object is described by the components $\left\{x\left(t_{i}\right) ; \mathrm{x}\left(\mathrm{t}_{\mathrm{i}}+\tau\right)\right\}$ of the time series $\left(X\left(t_{i}\right)\right)_{i=1}^{N}$.

The phase portrait allows to identity the system behavior features important from the stability point of view. To search for an attractor in the case of two (three) factors a phase 
space is constructed and the position of phase points is analyzed. If they are distributed uniformly, then the attractor existence hypothesis isn't confirmed.

The phase portraits constructed for the time series shown in Fig.1 are represent in Fig 3. The value of the time delay $\tau$ is 1 year.

When fig. 3 is closely examined, it's seen that there are two areas of phase points thickening. They can be considered as the split attractor.

In other words, attractor bifurcation takes place. Usually it's connected with appearance in the system of such state changes which can be interpreted as spasmodic or close to them. In the electrical conductivity of agricultural soils data analysis the attractor bifurcation entails sudden crisis change of system condition with high probability.

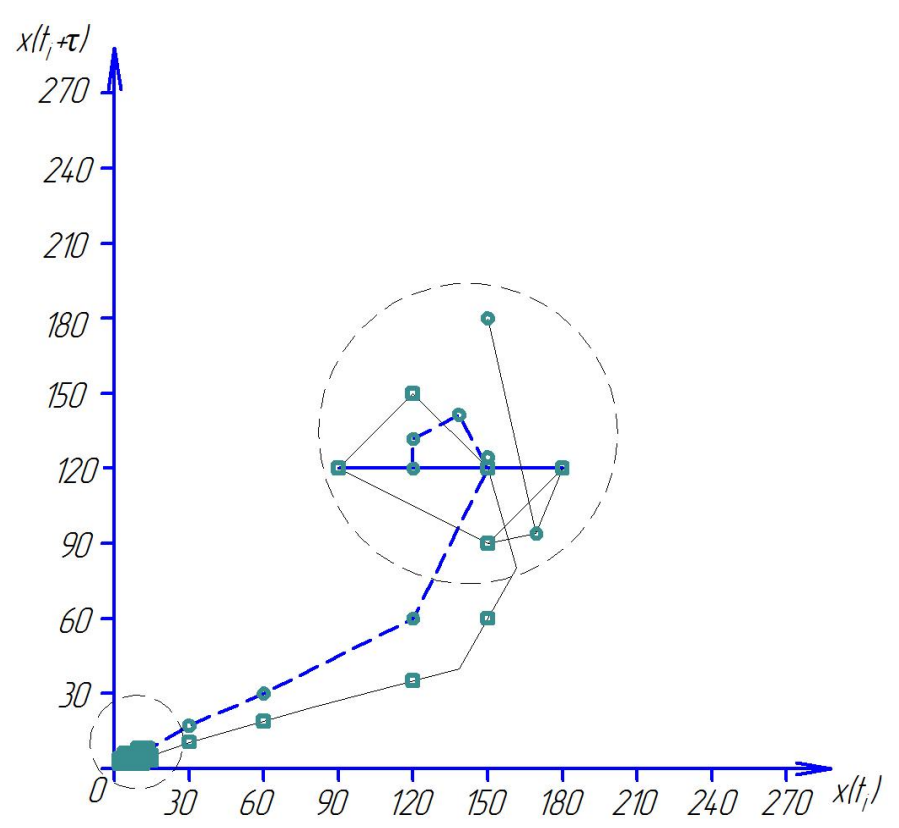

Fig. 3. Phase portraits of the time series

\section{Conclusion}

The value of the highest characteristic Lyapunov's indicator $\lambda\left(x_{1}\right) \approx 1,18$ demonstrates randomness in dynamics of the studied indicator.

The computed value of the fractality index, which is the stability indicator for the initial time series ,is $\mu=0,66 \cdot x \pm 0,073$, i.e. $\mu \succ 0,5$ This value is interpreted as flat,which indicates the condition of relative stability for the studied process. In other words, extreme changes in the electrical conductivity parameters of agricultural soils aren't predicted in the nearest future.

The evaluation of the correlation ratio is $C=-0,88$. It implies almost complete absence of influence of the present on the future in the studied time series, which also confirms the series trendlessness hypothesis .

The analysis of the phase portraits of time series, in particular detection of the attractor bifurcation, gives reason to speak about a possible spike or spasmodic change of the electrical conductivity parameters of agricultural soils.

\section{Список використаної літератури}

1. Takens F., Rand D.A., Young L.S. Detecting strange attractors in turbulence II Dynamical systems and Turbulence. Lecture Notes in Mathematics. Berlin: SpringerVerlag, 1981. Vol. 898. P. 366-381. 
2. Мун Ф. Хаотические колебания. Вводный курс для научных работников и инженеров. Москва: Мир, 1990. 312 с.

3. Hausdorff F. Dimension und Assures Mass. Matematishe Annalen. Berlin, 1919. Vol.79. P. $157-179$.

4. Федер Е. Фракталы. Москва: Мир,1991. 262 с.

5. Кроновер Р. Фракталы и хаос в динамических системах. Москва: Постмаркет, 2000. $352 \mathrm{c.}$

6. Безручко Б.П., Смирнов Д.А. Математическое моделирование и хаотические временные ряды. Саратов: ГосУНЦ «Колледж», 2005. 320 с.

7. Добовуков М.М, Кранев А.В., Старченко Н.В. Размерность минимального покрытия и локальный анализ фрактальных временных рядов. Вестник РУДН. 2004. T. 3, №1. С. 81-95.

8. Малинецкий Г.Г., Потапов А.Б., Подлазов А.В. Нелинейная динамика. Подходы, результаты, надежды. Москва: Комкнига, 2006. 216 с.

9. Figliola A., Serrano E., Paccosi G. About the effectiveness of different methods for the estimation of the multifractal spectrum of natural series. International Journal of Bifurcation and chaos. 2010. Vol. 20 (2). P. 331-339.

10. Delignieres D., Torre K. Fractal dynamics of human gait: a reassessment of the 1996 data of Hausdorff et al. Journal of Applied Physiology. 2009. Vol. 106. P. 1772-1279.

11. Старченко Н.В. Локальный анализ хаотических временных рядов с помощью индекса фрактальности: автореф. дисс. ... канд. физ.-мат. наук. Москва, 2005. 22 с.

\section{References}

1. Takens, F., Rand, D.A. \& Young, L.S. (1981). Detecting strange attractors in turbulence II Dynamical systems and Turbulence. Lecture Notes in Mathematics. Berlin: SpringerVerlag. 898, 366-381.

2. Mun, F. (1990) Chaoticheskie kolebanija. Vvodnyi kurs dlija nauchnich rabotnikov und ingenerov. Moskva: Mir.

3. Hausdorff, F. (1919). Dimension und Assures Mass. Matematishe Annalen. Berlin.79, $157-179$.

4. Feder, F. (1991). Fraktali. Moskva: Mir.

5. Kronover, R. (2000). Fraktali und chaos v dinamicheskich sistemach. Moskva: Postmarket.

6. Bezruchko, B.P. \& Smirnov, D.A. (2005). Matematicheskoje modelirovanije i chaoticheskije vremennije ryadi. Saratov: GosUNC "Kolledg".

7. Dobovukov, M.M., Kranev, A.V. \& Starchenko, N.V. (2004). Razmernost minimalnogo pokritija und lokalniji analis fraktalnich vremennich ryadov. Vestnik RUDN. 3, 1, 81-95.

8. Malinetsky, G.G., Potapov, A.V. \& Podlazov, A.V. (2006). Nelinejnaja dinamika. Podchodi, rezultati, nadegdi. Moskva: Komkniga.

9. Figliola, A., Serrano, E. \& Paccosi, G. (2010). About the effectiveness of different methods for the estimation of the multifractal spectrum of natural series. International Journal of Bifurcation and chaos. 20 (2), 331-339.

10. Delignieres, D. \& Torre, K. (2009). Fractal dynamics of human gait: a reassessment of the 1996 data of Hausdorff et al. Journal of Applied Physiology. 106, 1772-1279.

11. Starchenko, N.V. (2005). Lokalnij analiz chaoticheskich vremennich ryadov s pomoschju indeksa fraktalnosti: avtoref. diss. ... kand. fiz.- mat. nauk. Moskva. 
Броварець Олександр Олександрович - доцент, к.т.н., завідувач кафедри інформаційно-технічних та природничих дисциплін Київського кооперативного інституту бізнесу і права. E-mail: brovaretsnau@ukr.net, orcid.org/0000-0002-4906-238X.

Човнюк Юрій Васильович - доцент, к.т.н., доцент кафедри сільськогосподарських машин та системотехніки Національного університету біоресурсів i природокористування України, E-mail: ychovnyuk@ukr.net, ORCID 0000-0002-06080203.

Кравчук Володимир Тимофійович - доцент, к.т.н., доцент кафедри охорони праці та навколишнього середовища Київського національного університету будівництва i архітектури. E- mail: vtk1@ukr.net, ORCID 0000-0002-5213-3644.

Іванов Євген Олександрович - старший викладач кафедри іноземних мов Національного авіаційного університету. E-mail: shifango@ukr.net, ORCID 0000-00021318-0472. 